\title{
CHANGES OF NUTRIENT CONTENTS IN TOMATO FRUITS UNDER THE INFLUENCE OF INCREASING INTENSITY OF MANGANESE NUTRITION
}

\author{
ZMIANY ZAWARTOŚCI SKŁADNIKÓW POKARMOWYCH \\ W OWOCACH POMIDORA POD WPLYWEM \\ WZRASTAJĄCEJ INTENSYWNOŚCI ŻYWIENIA MANGANEM
}

\begin{abstract}
The aim of conducted in years 2008-2012 studies was to assess the efficiency of application of increasing manganese levels on the nutritive value of tomato fruits (Lycopersicon esculentum Mill. cvs. 'Alboney $\mathrm{F}_{1}$ ' and 'Emotion $\mathrm{F}_{1}$ '), expressed in the contents of macro- and micronutrients. Plants were grown in rockwool with application of nutrient solution characterized the following chemical composition (in [mg dm ${ }^{-3}$ ): $\mathrm{N}_{-} \mathrm{NH}_{4}$ $2.2, \mathrm{~N}_{-} \mathrm{NO}_{3}-230, \mathrm{P}-50, \mathrm{~K}-430, \mathrm{Ca}-145, \mathrm{Mg}-65, \mathrm{Cl}-35, \mathrm{~S}-\mathrm{SO}_{4}-120, \mathrm{Fe}-2.48, \mathrm{Zn}-0.50, \mathrm{Cu}-0.07, \mathrm{pH}-$ $5.50, \mathrm{EC}-3.00 \mathrm{mS} \mathrm{cm}$. The following manganese plant nutrition levels were examined (in $\mathrm{mg} \mathrm{Mn} \cdot \mathrm{dm}^{-3}$ ): 0.06 (control), 0.3, 0.6, 1.2 (Experiment I), 2.4, 4.8, 9.6 and 19.2 (Experiment II); (denoted as Mn-0, Mn-0.3, $\mathrm{Mn}-0.6, \mathrm{Mn}-1.2, \mathrm{Mn}-2.4, \mathrm{Mn}-4.8, \mathrm{Mn}-9.6 ; \mathrm{Mn}-19.2)$. The source of manganese was manganese sulfate $\left(\mathrm{MnSO}_{4}\right.$. $\mathrm{H}_{2} \mathrm{O}, 32.3 \% \mathrm{Mn}$ ). The nutritive value of tomato fruits changed significantly under the influence of the application of wide range of manganese concentrations. It was found a significant reduction of the content of phosphorus (Exp. I, II), potassium (Exp. II), calcium (Exp. I, II) and magnesium (Exp. I, II). Manganese influence on the decreasing content of other metallic micronutrients $(\mathrm{Fe}, \mathrm{Zn}, \mathrm{Cu})$ in fruits. Cultivar had a significantly influence on the content of: nitrogen (except Mn-2.4, Mn-4.8, Mn-9.6), potassium (in Exp. II, except Mn-4.8), calcium (except for Mn-0.6, Mn-2.4), magnesium (except Mn-0.3 and Mn-2.4), iron (except Mn-1.2), manganese and zinc (except control combination) and copper (except Mn-0.6 and Mn-1.2). The highest contents of $\mathrm{N}, \mathrm{Ca}$ and $\mathrm{Mg}$ in fruits were recorded for the application of $\mathrm{Mn}-0$, while for $\mathrm{P}$ and $\mathrm{K}-$ at $0.3 \mathrm{mg} \mathrm{Mn} \mathrm{dm}{ }^{-3}$, whereas it was lowest for all these nutrients (except $\mathrm{N}$ ) in the case of Mn-19.2 (Exp. II). The reduction of nutrient contents amounted to (\% changes: from the lowest content to the highest content): N (11.3), P (48.1), K (24.8), Ca (75.4), Mg (57.5), $\mathrm{Fe}$ (59.2), $\mathrm{Zn}(65.4)$ and $\mathrm{Cu}(43.7)$.
\end{abstract}

Keywords: manganese, tomato fruits, macroelements, microelements

Manganese $(\mathrm{Mn})$ as a metallic microelement serves numerous physiological functions in plants [1-4]. However, there are no current studies in available literature concerning feeding efficiency and tolerance to that nutrient in tomato in hydroponic culture run in rockwool. Manganese at quantitative advantage may lead to a reduced uptake of other nutrients [5,6]. Parameters determining the value of consumed fruits and vegetables include

\footnotetext{
${ }^{1}$ Department of Plant Nutrition, University of Life Sciences in Poznan, ul. Zgorzelecka 4, 60-199 Poznań, Poland, email: tkleiber@up.poznan.pl
} 
their contents of bioactive compounds or nutrients, ie macro- and micronutrients. Nutrition is one of the factors influencing the nutritive value of tomato [7-9]. This is of particular importance in the case of this species, since the volume of tomato consumption in Poland is greatest among all vegetables [10].

Many studies [11-13] described as optimal manganese content range from 0.55 to $0.65 \mathrm{mg} \mathrm{Mn} \cdot \mathrm{dm}^{-3}$. What is important in plants cultivation using fertigation water quality is crucial [14]. Most of the groundwater to a depth of 100 meters contain up to $0.5 \mathrm{mg} \mathrm{Mn} \cdot \mathrm{dm}^{-3}$ [15] but about $5 \%$ of water used to prepare of nutrient solution contain from 1 to $4.5 \mathrm{mg} \mathrm{Mn} \cdot \mathrm{dm}^{-3}$. The possibility of water with a high content of manganese was confirmed in areas of intensive horticulture developed [16].

The aim of conducted studies was to assess changes in the nutritive value of tomato grown in rockwool under the influence of increasing manganese concentrations in nutrient solutions applied in fertigation, starting from insufficient contents up to excessive/toxic levels.

\section{Material and methods}

Experiments on the efficiency of tomato nutrition with manganese were conducted in the years 2008-2012 in a greenhouse of the Department of Plant Nutrition, the Poznan University of Life Sciences. The aim of these studies was to assess the effect of increasing manganese concentrations in tomato grown in rockwool on the nutritive value of fruits in terms of their contents of macro- and micronutrients. The experiments were conducted on 2 tomato cultivars (Lycopersicon esculentum Mill. cvs. 'Alboney $F_{1}$ ' and 'Emotion $F_{1}$ '). Plants were grown in standard rockwool $\left(100 \cdot 15 \cdot 7.5 \mathrm{~cm}, \mathrm{~V} 11.25 \mathrm{dm}^{3}, 60 \mathrm{~kg} \cdot \mathrm{m}^{-3}\right)$ at a stocking of 2.5 plants $\mathrm{m}^{-2}$. The experiments were established using the randomized complete block design in 4 replications.

The chemical composition of tap water, on the basis of which the nutrient solution for plant fertigation was prepared, was as follows (in $\left[\mathrm{mg} \mathrm{dm}^{-3}\right]$ ): $\mathrm{N}-\mathrm{NH}_{4}$ trace amounts, $\mathrm{N}-\mathrm{NO}_{3}$ - 3.7, $\mathrm{P}-\mathrm{PO}_{4}-0.3, \mathrm{~K}-1.8, \mathrm{Ca}-57.3, \mathrm{Mg}-13.4, \mathrm{~S}_{-} \mathrm{SO}_{4}-58.3, \mathrm{Na}-22.7, \mathrm{Cl}-42, \mathrm{Fe}-0.08$, $\mathrm{Mn}-0.06, \mathrm{Zn}-0.50, \mathrm{Cu}$ - trace amounts, $\mathrm{B}-0.011$, Mo - trace amounts, $\mathrm{HCO}_{3}-277.5$, $\mathrm{pH}-7.00, \mathrm{EC}-0.735 \mathrm{mS} \cdot \mathrm{cm}^{-1}$. Plants were fertigated with a standard nutrient solution with the following chemical composition (in $\left[\mathrm{mg} \mathrm{dm}^{-3}\right]$ ): $\mathrm{N}-\mathrm{NH}_{4} 2.2, \mathrm{~N}_{-} \mathrm{NO}_{3}-230, \mathrm{P}-50$, $\mathrm{K}-430, \mathrm{Ca}-145, \mathrm{Mg}-65, \mathrm{Cl}-42, \mathrm{~S}_{-} \mathrm{SO}_{4}-120, \mathrm{Fe}-2.48, \mathrm{Zn}-0.50, \mathrm{Cu}-0.07, \mathrm{pH}-5.50$, $\mathrm{EC}-3.00 \mathrm{mS} \cdot \mathrm{cm}^{-1}$. The following manganese plant nutrition levels were examined (in $\left[\mathrm{mg} \mathrm{Mn} \cdot \mathrm{dm}^{-3}\right]$ ): 0.06 - control, 0.3, 0.6, 1.2 (experiment I - 2008-2011 year), 2.4, 4.8, 9.6 and 19.2 (experiment II - 2012 year) - denoted as Mn-0, Mn-0.3, Mn-0.6, Mn-1.2, Mn-2.4, Mn-4.8, Mn-9.6 and Mn-19.2, respectively.

Manganese content at Mn- 0 combination corresponds to the content of this ion in water used to prepare the nutrient solution for plant fertigation. Manganese sulphate $\left(\mathrm{MnSO}_{4} \cdot \mathrm{H}_{2} \mathrm{O}, 32.3 \% \mathrm{Mn}\right)$ was the source of manganese in the other tested variants. To prepare nutrient solutions there were used following fertilizers: potassium nitrate $\left(13 \% \mathrm{~N}-\mathrm{NO}_{3}, 38.2 \% \mathrm{~K}\right)$, calcium nitrate $\left(14.7 \% \mathrm{~N}-\mathrm{NO}_{3}, 18.5 \% \mathrm{Ca}\right)$, magnesium nitrate $\left(11 \% \mathrm{~N}^{-N_{3}}, 9.5 \% \mathrm{Mg}\right)$, monopotassium phosphate $(22.3 \% \mathrm{P}, 28.2 \% \mathrm{~K})$, potassium sulphure $(44.8 \% \mathrm{~K}, 17 \% \mathrm{~S})$, magnesium sulphure $(9.9 \% \mathrm{Mg}, 13 \% \mathrm{~S})$, Librel FeDP7 (7\% $\mathrm{Fe})$, copper sulphate $(25.6 \% \mathrm{Cu})$, borax $(11.3 \% \mathrm{~B})$ and sodium molibdate $(39.6 \% \mathrm{Mo})$. To regulated $\mathrm{pH}$ values there were used nitric acid $(38 \%)$. 
The fertilizer rate in the nutrient solution depended on the development phase of plants and climatic conditions in the greenhouse. In the period of intensive yielding of plants and high temperatures (June - July) daily $3.0-3.5 \mathrm{dm}^{3}$ nutrient solution per plant were used in 15-20 single doses, with 20-30\% effusion of drain water from the slabs.

In the course of vegetation experiments in the last decade of August in each of the years of the study representative samples of fruits were collected for chemical analyses. Collected fruits were dried at $45-50^{\circ} \mathrm{C}$ and then ground. For assays of total nitrogen, phosphorus, potassium, calcium and magnesium the plant material was mineralized in concentrated sulphuric acid [17]. After mineralization of the plant samples, chemical analyses were performed using the following methods: N-total according to Kjeldahl in a Parnas-Wagner distillation apparatus, $\mathrm{P}$ - by colorimetry with ammonium molybdate, and $\mathrm{K}, \mathrm{Ca}, \mathrm{Mg}$ by atomic absorption spectrometry (in a Carl Zeiss Jena apparatus). In the determinations of total iron, manganese, zinc and copper the plant material was mineralized in a mixture of dioxonitric and tetraoxochloric acids $(3: 1 \mathrm{v} / \mathrm{v})$. After mineralization $\mathrm{Fe}$, $\mathrm{Mn}, \mathrm{Zn}$ and $\mathrm{Cu}$ were determined according to ASA. Results of chemical analyses of plants for their contents of macro- and microelements were analyzed statistically using the Duncan test, with inference at the significance level $\alpha=0.05$.

\section{Results and discussion}

It was found an influence of manganese nutrition on the yield and visual symptoms of deficity/toxicity present on plants [18]. In the control combination (Mn-0) deficiency symptoms were observed in leaves (after a 3-week exposure to a lack of this nutrient supplementation in the fertilizer). Within the range up to Mn-2.4 no visual symptoms of toxicity are observed in plants. They were found the fastest (after 1.5-month exposure) in Mn-19.2 and the latest (after 3-month application of the nutrient solution at the same Mn concentration) for Mn-4.8. Even when using nutrient solution containing $1.2 \mathrm{mg} \mathrm{Mn} \cdot \mathrm{dm}^{-3}$ was a significant reduction in marketable yield - while the plants were not observed symptoms resulting from excessive nutrient manganese.

In the conducted studies a significant effect of manganese was found on the content of nitrogen in fruits (Fig. 1). The highest average content of this nutrient (2.03\%) was found in the Mn-0 combinations (Exp. I) - within range to Mn-1.2 was significantly lower. In experiment II the lower nitrogen content $(1.80 \% \mathrm{~N})$ was found in case of Mn-19.2. Cultivar - except Mn-2.4, Mn-4.8, Mn-9.6 - had significant effect on nitrogen content in fruits. In all the tested combinations the recorded contents of nitrogen were similar to the levels reported in literature. The content of nitrogen in fruits could be significantly affected by the substrate used in plant culture [19]. In the case of rockwool culture the mean content of this nutrient was $1.68 \% \mathrm{~N}$, in coconut fiber it was $1.47-1.75 \% \mathrm{~N}$ (depending on its type), while in peat culture it was as high as $2.59 \% \mathrm{~N}$. Important factor influenced on nitrates content is also source of potassium [20] and plant nutrition with phosphorus [7]. Mean nitrogen contents in tomato fruits are not modified either by the cultivar or the $\mathrm{K}: \mathrm{Ca}: \mathrm{Mg}$ ratios and they amount to $1.98-2.08 \%$ [21]. Nzanza [22] reported that depending on the varied $\mathrm{K}$ and $\mathrm{Mg}$ nutrition, mean content of nitrogen in fruits range from 2.28 to $2.39 \%$, while Pivot et al [23] claimed that optimal content of $\mathrm{N}$ is tomato fruits is $2.52 \%$. 


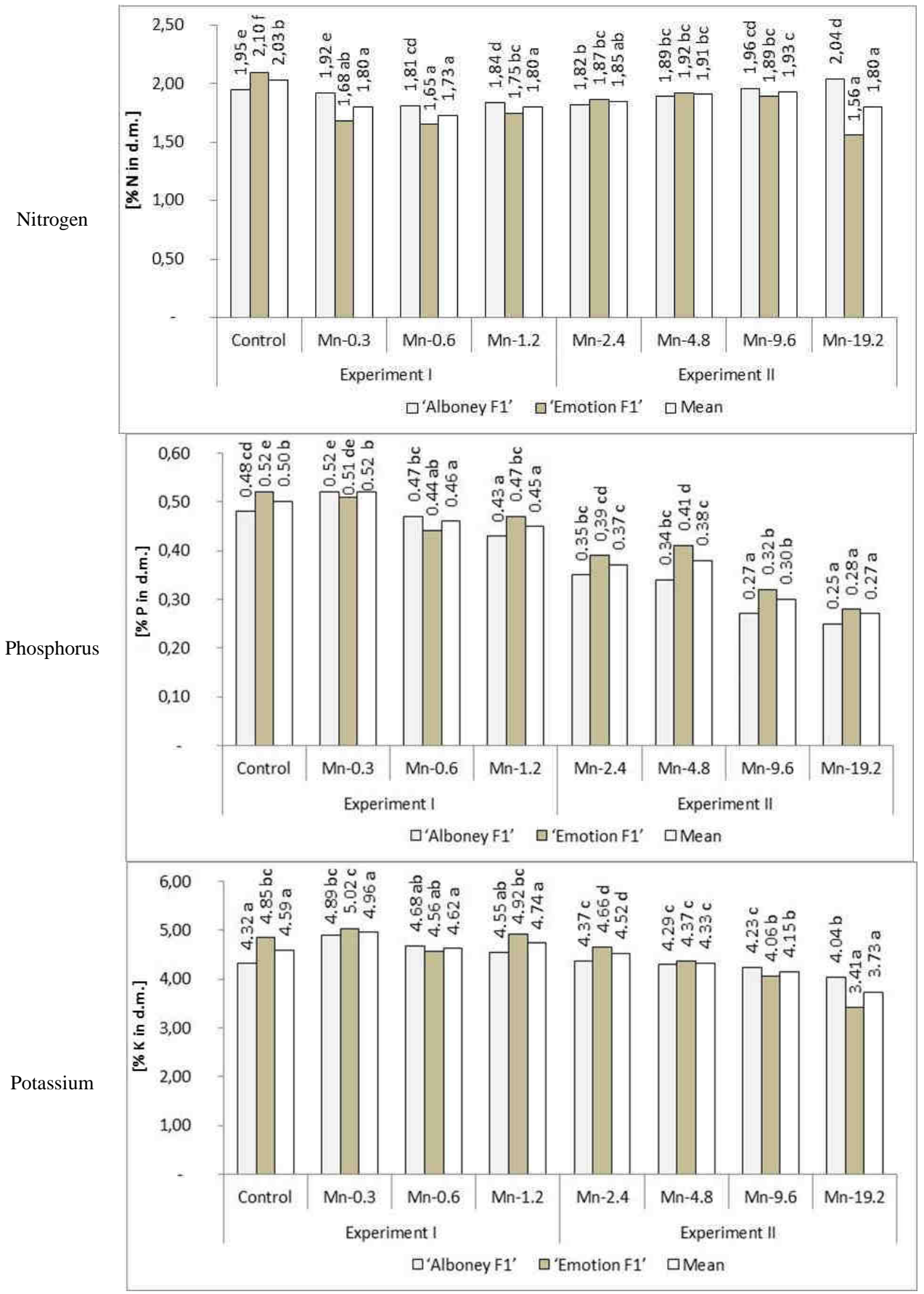

Fig. 1. The manganese influence on the content of nitrogen, phosphorus and potassium in tomato fruits 
The highest content of phosphorus were recorded in the case of $\mathrm{Mn}-0$ and $\mathrm{Mn}-0.3$ (respectively 0.50 and $0.52 \%$ P, Exp. I, Fig. 1) - but in case of Mn-0.6 and Mn-1.2 was significantly lower. Decreasing trend was confirmed in experiment II - the lowest phosphorus content $(0.27 \% \mathrm{P})$ was found for Mn-19.2. Effect of variety on the phosphorus content was varied. Similarly as in the case of nitrogen, phosphorus contents detected in fruits in this study were similar to those cited in literature. It may be influenced by source of phosphorus [7] or by cultivar [21, 24]. Ion ratios in the nutrient solution applied in fertigation do not have a significant effect on the content of phosphorus in fruits (the range of $0.49-0.52 \% \mathrm{P}$ ), while Chapagain and Wiesman [20] claimed that potassium source do not influence too. Depend on the varied $\mathrm{K}$ and $\mathrm{Mg}$ nutrition mean content of $\mathrm{P}$ in fruits is $0.46-0.55 \%$ [22] what is similar to determined in described studies for optimal Mn nutrition. Lower content of phosphorus was also determined [23].

A significant variation in potassium content in fruits was recorded in this study (Fig. 1). It was found no significantly difference of average content within range of manganese to Mn-1.2 (experiment I; 4.59-4.96\% K). But within range from Mn-2.4 to Mn-19.2 the content of potassium significantly decreased. The lowest content of this nutrient was detected at Mn-19.2 (3.73\% K). In experiment I cultivar did not influence (except control combination) - but in experiment II (except Mn-4.8) - significantly influenced on the content of potassium in fruits. The recorded contents of this nutrient in fruits were similar to those given by other authors [23]. The growing medium has a significant effect on the content of potassium in tomato fruits [19]. In the case of rockwool culture the content of this nutrient was $4.61 \% \mathrm{~K}$, while in peat it was $5.09 \% \mathrm{~K}$. Cultivar [24] as well phosphorus nutrition [7] may also be factors significantly modifying the content of potassium in fruits. Also plant nutrition has a significant effect on the mean content of this nutrient, which ranges from $2.97 \%$ (at the predominance of $\mathrm{Ca}$ in nutrient solution) to $3.59 \% \mathrm{~K}$ (at the predominance of $\mathrm{K}$ in nutrient solution) [21]. Chapagain and Wiesman [20] claimed that differed potassium treatment do not influence on content of that nutrient in tomato fruits.

Within range up to Mn-1.2 it was found significantly decreasing of calcium content in tomato fruit. The highest content of calcium recorded at Mn-0 (0.57\% Ca; Exp. I, Fig. 2). The recorded calcium contents in fruits accompanying the best marketable yielding in plants [19] were markedly higher than those reported by other authors. Cultivar had a significant effect (except for Mn-0.6, Mn-2.4) on calcium content in fruits. Within range to Mn-19.2 (Exp. II) it was found significantly decreasing trends of calcium content. Calcium content in fruits could be significantly modified by the growing medium [19]. The lowest amounts of this nutrient were contained in fruits harvested from plants grown in rockwool $(0.15 \% \mathrm{Ca})$ in comparison to those grown in coconut fiber $(0.16-0.19 \% \mathrm{Ca})$ or peat $(0.20 \% \mathrm{Ca})$. The modifying effect of the substrate was also confirmed in other studies [25]. Between other factors influenced significantly on calcium content in tomato fruit is also cultivar [24]. Lower content of calcium than determined for optimal manganese nutrition was determined earlier [23].

Similarly as in the case of phosphorus and calcium, a significant reduction of magnesium content in fruits was observed with an increase in the intensity of manganese nutrition in tomato (both in experiment I and II) (Fig. 2). Cultivar - except for Mn-0.3 (Exp. I) and Mn-2.4 (Exp. II) significantly influence the content of this nutrient in fruits. Opinions on the modifying effect of the growing medium on the content of magnesium in 
fruits are contradictory [19]. Potassium treatment [20] and cultivar [24] may significantly influence on $\mathrm{Mg}$ content in fruits.
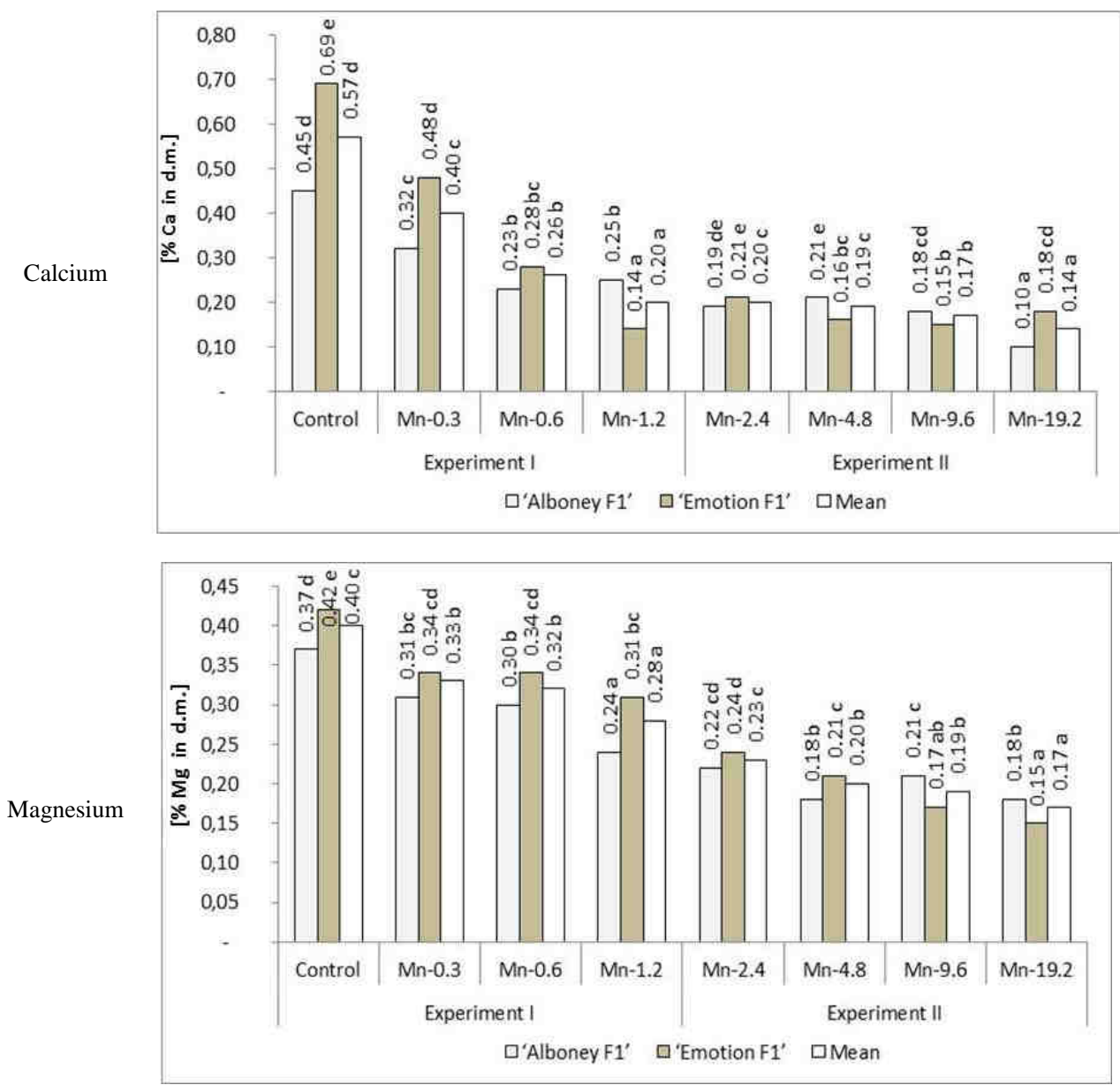

Fig. 2. The manganese influence on the content of calcium and magnesium in tomato fruits

It was found lowering trends of iron content (both within range up to Mn-1.2 and Mn-2.4 - Mn-19.2) in fruits (Fig. 3). Mean contents of iron were reduced from $90.5 \mathrm{mg} \mathrm{Fe} \cdot \mathrm{kg}^{-1}$ d.m. to $36.9 \mathrm{mg} \mathrm{Fe} \cdot \mathrm{kg}^{-1}$ d.m. (for Mn-0 and Mn-19.2, respectively). Cultivar significantly influenced on the content of mentioned nutrient (except Mn-1.2). One of factor influenced on the content of iron in fruits is varied nutrition of tomato with phosphorus [7]. Also the used substrate has a significant effect on the content of this nutrient in fruits. Significantly greater contents of iron $\left(87.5 \mathrm{mg} \mathrm{Fe} \cdot \mathrm{kg}^{-1}\right.$ d.m.) were found in fruits from plants grown in rockwool than in those from peat culture $\left(62.3 \mathrm{mg} \mathrm{Fe} \cdot \mathrm{kg}^{-1}\right.$ d.m.) or grown in coconut fiber $\left(56.7-69.7 \mathrm{mg} \mathrm{Fe} \cdot \mathrm{kg}^{-1}\right.$ d.m.) [19]. It was confirmed that cultivar [24] and type of cultivation [25] may also significantly influence the content of this 
microelement in fruits. Iron contents detected by Olaniyi et al [24] were markedly lower (15.36-31.09 $\mathrm{mg} \mathrm{Fe} \cdot \mathrm{kg}^{-1}$ d.m.) than those recorded in this study.

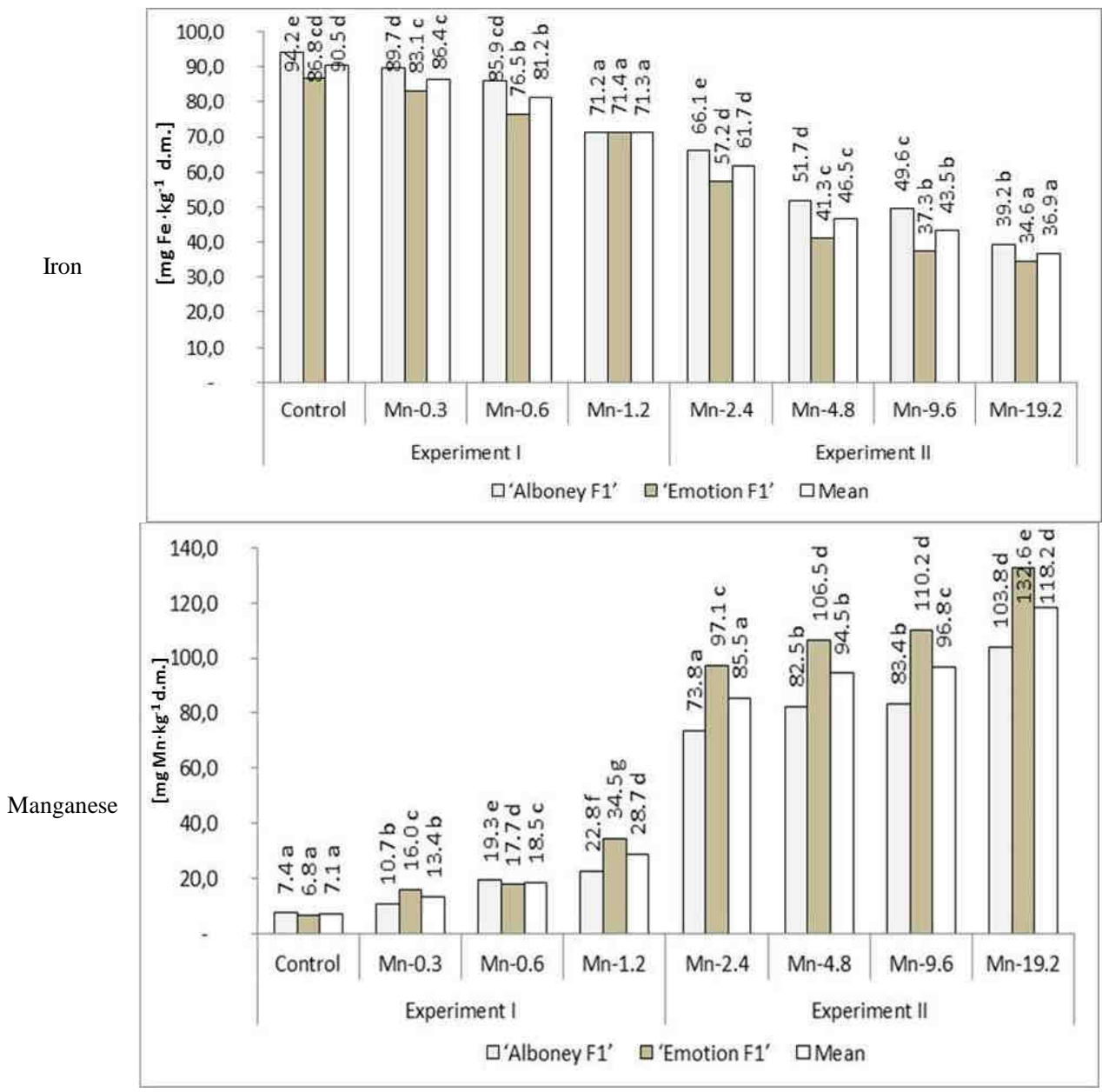

Fig. 3. The manganese influence on the content of iron and manganese in tomato fruits

It was found significantly increasing trend of manganese content in tomato fruits (both in experiment I and II; Fig. 3). Generally cultivar influenced on the content of nutrient (except control combination). Lower content of manganese was measured in case soil tomato cultivation by Nwajei et al [26].

A similar dependence as that in case of iron was observed for zinc (Fig. 4). Contents of this nutrient with an increase in the intensity of manganese nutrition were reduced from 39.6 to $22.4 \mathrm{mg} \mathrm{Zn} \cdot \mathrm{kg}^{-1}$ d.m. (Exp. I) and from 19.2 to $13.7 \mathrm{mg} \mathrm{Zn} \cdot \mathrm{kg}^{-1}$ d.m. (Exp. II). Cultivar significantly modified the content of zinc in fruits (except control combination). Zinc nutrition significantly modifies the content of this nutrient in tomato fruits (the range of 34.33-45.67 $\mathrm{mg} \mathrm{Zn} \cdot \mathrm{kg}^{-1}$ ) [8]. Zinc content in fruits was also influenced by plant nutrition 
with phosphorus [7]. Also the substrate has a significant effect on the content of this microelement in fruits [19]. In the case of the standard rockwool culture the content of zinc is $19.3 \mathrm{mg} \mathrm{Zn} \cdot \mathrm{kg}^{-1}$, in coconut fiber it is $13.7-26.6 \mathrm{mg} \mathrm{Zn} \cdot \mathrm{kg}^{-1}$, while the lowest amounts are recorded in peat culture $\left(13.2 \mathrm{mg} \mathrm{Zn} \cdot \mathrm{kg}^{-1}\right)$.

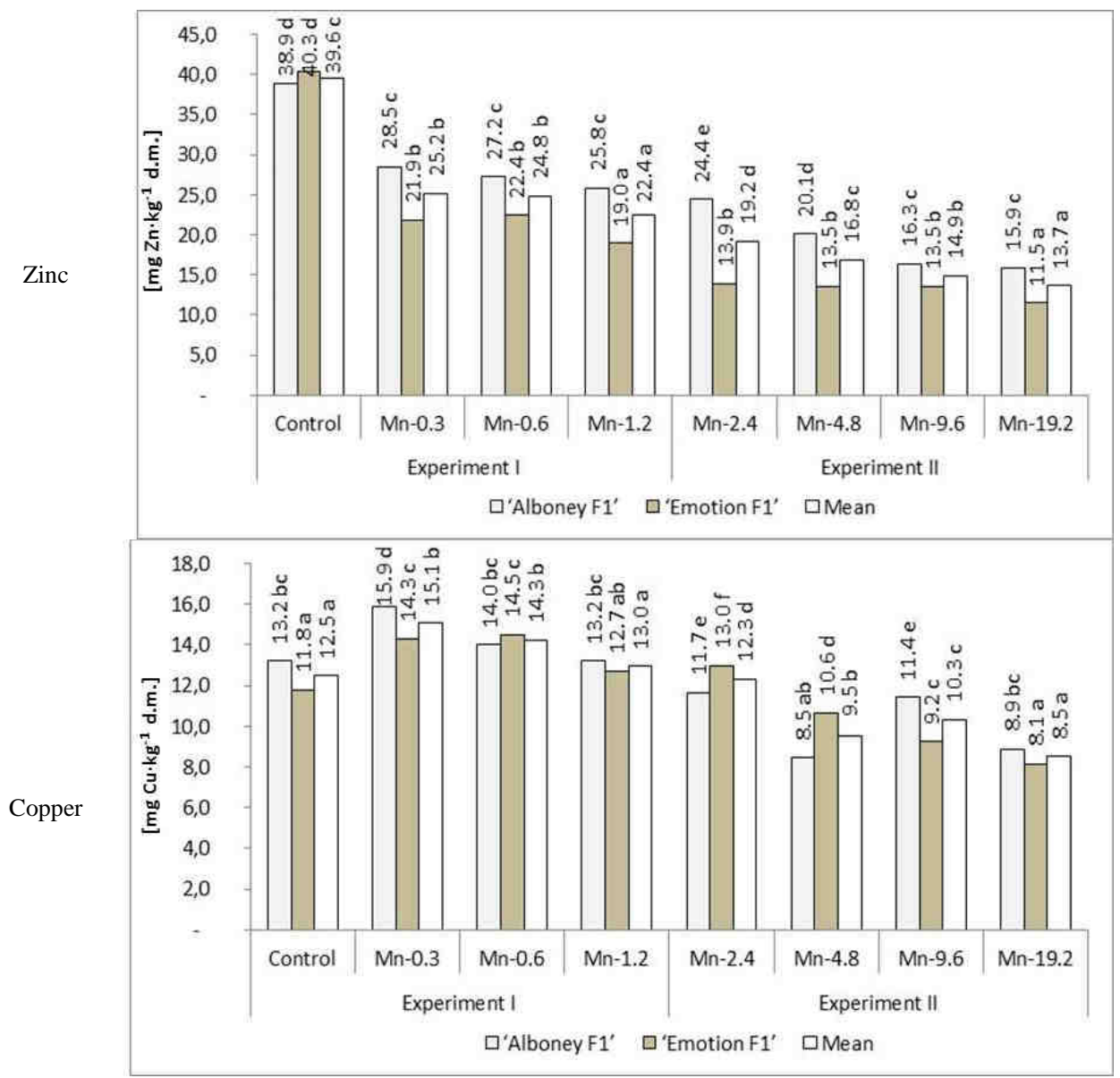

Fig. 4. The manganese influence on the content of zinc and copper in tomato fruits

The content of copper in Mn- 0.3 and Mn- 0.6 was significantly higher than in case of control combination and Mn-1.2. In range from Mn-2.4 (Exp. II) it was found decreasing tendency of mention nutrient in tomato fruits (from 12.3 to $8.5 \mathrm{mg} \mathrm{Cu} \cdot \mathrm{kg}^{-1}$ d.m.). The content of this nutrient in fruits was affected by cultivar (except Mn 0.6 and Mn-1.2). Between factor influence on content of copper in fruits are: growing medium [19] and source of phosphorus [7].

The Directive of the European Commission (EC) no. 1881/2006 of 19 December 2006 [27] specifies the highest admissible levels of certain contaminants in foodstuffs. The heavy metals covered by the standards include lead, cadmium and mercury, while it is not 
manganese, which from the physiological point of view is a microelement and at the same time a heavy metal.

Based on conducted studies it can be concluded that with the increase of the content of manganese in the nutrient solution above the recommended content, is substantially modified nutritional value of fruits. Mn concentration range where significant deterioration is observed yield of tomato [18] found the reduction of phosphorus, potassium, calcium, magnesium, iron, zinc and copper in the fruit.

\section{Conclusions}

In the conducted studies on changes in the nutritive value of tomato fruits under the influence of an increasing intensity of manganese nutrition the following was shown:

1. The nutritive value of tomato fruits changes significantly under the influence of the application of excessive/toxic manganese concentrations.

2. A significant reduction of the content of phosphorus (Exp. I, II), potassium (Exp. II), calcium (Exp. I, II) and magnesium (Exp. I, II) in fruits with an increase in Mn-level. The highest contents of $\mathrm{N}, \mathrm{Ca}$ and $\mathrm{Mg}$ in fruits were recorded for the application of $\mathrm{Mn}-0$, while for $\mathrm{P}$ and $\mathrm{K}-$ at $0.3 \mathrm{mg} \mathrm{Mn} \cdot \mathrm{dm}^{-3}$, whereas it was lowest for all these nutrients (except $\mathrm{N}$ ) in the case of Mn-19.2 (Exp. II).

3. It was found the significantly increasing trends of manganese in tomato fruits under the increasing manganese nutrition.

4. An effect of manganese on the decreasing content of the other metallic microelements, ie iron, zinc and copper in fruits. The highest contents of $\mathrm{Fe}$ and $\mathrm{Zn}$ were recorded in the case of $\mathrm{Mn}-0$, while for $\mathrm{Cu}$ it was at $\mathrm{Mn}-0.3$, and the lowest contents of these nutrients were observed for Mn-19.2.

5. A reduction of contents of nutrients in fruits amounted to ( $\%$ changes in nutrient content: the greatest content to the recorded lowest content): $\mathrm{N}$ (11.3), $\mathrm{P}$ (48.1), $\mathrm{K}$ (24.8), $\mathrm{Ca}$ (75.4), $\mathrm{Mg}$ (57.5\%), Fe (59.2), Zn (65.4) and $\mathrm{Cu}$ (43.7).

\section{References}

[1] Ducic T, Polle A. Transport and detoxification of manganese and copper in plants. Braz J Plant Physiol. 2005;17:103-112. DOI: http://dx.doi.org/10.1590/S1677-04202005000100009.

[2] Humphries JM, Stangoulis JCR, Graham RD. Manganese. In: Handbook of Plant Nutrition Barker AV, Pilbeam DJ, editor. Boca Raton FL: Taylor \& Francis Group; 2007:351-374.

[3] Millaleo R, Reyes-Díaz M, Ivanov AG, Mora ML, Alberdi M. Manganese as essential and toxic element for plants: transport, accumulation and resistance mechanisms. J Soil Sci Plant Nutr. 2010; 10(40): 476-494. DOI: http://dx.doi.org/10.4067/S0718-95162010000200008.

[4] Lidon FC, Barreiro M, Ramalho J. Manganese accumulation in rice: implications for photosynthetic functioning. J. Plant Physiol. 2004;161:1235-1244. DOI:10.1016/j.jplph. 2004.02.003.

[5] Savvas D, Papastavrou D, Ntatsi G, Ropokis A, Olympios C. Interactive effects of grafting and manganese supply on growth, yield, and nutrient uptake by tomato. Hort Science. 2009;44(7):1978-1982.

[6] Shenker M., Plessner OE, Tel-Or E. Manganese nutrition effects on tomato growth, chlorophyll concentration, and superoxide dismutase activity. J Plant Physiol. 2004;161: 197-202. DOI: http://dx.doi.org/10.1078/0176-1617-00931.

[7] Gad N, Kandil H. Influence of cobalt on phosphorus uptake, growth and yield of tomato. Agric Biol J N Am. 2010;1(5):1069-1075. DOI: 10.5251/abjna.2010.1.5.1069.1075.

[8] Salam MA, Siddique MA, Rahim MA, Rahman MA, Saha MG. Quality of tomato (Lycopersicon esculentum Mill.) as influenced by boron and zinc under different levels of NPK fertilizers. Bangladesh J Agril Res. 2010;35(3):475-488. DOI:10.3329/bjar.v35i3.6454. 
[9] Jędrszczyk E. Effect of potassium foliar nutrition on changes in the content of carotenoid pigments and on some parameters of the nutritional value of tomato fruit. Vegetable Crops Res Bull. 2010;72:105-114. DOI: $10.2478 / \mathrm{v} 10032-010-0010-2$.

[10] Główny Urząd Statystyczny. Sytuacja gospodarstw domowych w 2011 r. w świetle wyników badania budżetów gospodarstw domowych. Warszawa 2012:1-20.

[11] Jarosz Z, Michałojć Z, Dzida K. Changes in the chemical composition of the rhizosphere of tomato grown on inert substrates in a prolonged cycle. J Elem. 2011;16(3):387-396. DOI: 10.5601/jelem.2011.16.3.04.

[12] Jarosz Z, Dzida K, Nurzyńska-Wierdak R. Possibility of reusing expanded clay in greenhouse tomato cultivation. Part II. Changes in the composition of nutrients in the root environment and leaves. Acta Sci Pol Hortorum Cultus. 2012;11(6):131-143.

[13] Kowalczyk K, Gajc-Wolska J. Effect of the kind of growing medium and transplant grafting on the cherry tomato yielding. Acta Sci Pol. Hortorum Cultus. 2011;10(1):61-70.

[14] Breś W, Kleiber T, Trelka T. Quality of water used for drip irrigation and fertigation of horticultural plants. Folia Hort. 2010;22(2):67-74. DOI: 10.2478/fhort-2013-0161.

[15] Górski J. Kształtowanie się jakości wód podziemnych utworów czwartorzędowych w warunkach naturalnych oraz wymuszonych eksploatacją. Warszawa: IKŚ; 1981.

[16] Kowalczyk W, Dyśko J, Felczyńska A. Ocena stopnia zanieczyszczenia składnikami nawozowymi wody z ujęc głębinowych na terenach o skoncentrowanej produkcji szklarniowej. http://www.inhort.pl/files/nowosci_warzywnicze/2010/tom_51/nw51_3.pdf.

[17] Metody badań laboratoryjnych w stacjach chemiczno-rolniczych. Cz. III. Badanie gleb, ziemi podłoży spod warzyw i kwiatów oraz części wskaźnikowych roślin w celach diagnostycznych. Puławy: IUNG; 1983:28-81.

[18] Kleiber T. Influence of manganese on yielding of tomato (Lycopersicon esculentum Mill.) cultivated in rockwool. Nauka Przyr Technol. 2014:8(2):14.

[19] Kleiber T, Markiewicz B, Niewiadomska A. Organic substrates for intensive horticultural cultures: Yield and nutrient status of plants, microbiological parameters of substrates. Pol J Environ Stud. 2012;21(5):1261-1271.

[20] Chapagain BP, Wiesman Z. Effect of potassium magnesium chloride in the fertigation solution as partial source of potassium on growth, yield and quality of greenhouse tomato. Scientia Horticulturae. 2004;99:279-288. DOI:10.1016/S0304-4238(03)00109-2.

[21] Fanasca S, Colla G, Maiani G, Venneria E, Rouphael Y, Azzini E, et al. Changes in antioxidant content of tomato fruits in response to cultivar and nutrient solution composition. J Agric Food Chem. 2006;54:4319-4325. DOI: 10.1021/jf0602572.

[22] Nzanza B. Yield and quality of tomato as influenced by differential $\mathrm{Ca}, \mathrm{Mg}$ and $\mathrm{K}$ nutrition. Pretoria: Department of Plant Production and Soil Science. Faculty of Natural and Agricultural Sciences, University of Pretoria; 2010.

[23] Pivot D, Reist A, Gillioz JM, Ryser JP. Water quality, climatic environment and mineral nutrition of tomato (Lycopersicon esculentum) in closed soilless cropping system. Acta Hort. 1998;458: 207-214

[24] Olaniyi JO, Akanbi WB, Adejumo TA, Akande OG. Growth, fruit yield and nutritional quality of tomato varieties. Afric J Food Sci. 2010;4(6):398-402. DOI: 10.5897/AJFS.

[25] Premuzic Z, Bargiela M, Garcia A, Rendina A, Iorio A. Calcium, iron, potassium, phosphorus and vitamin C content of organic and hydroponic tomatoes. Hort Science. 1998;33(2):255-257.

[26] Nwajei GE, Okwagi P, Nwajei RI, Obi-Iyeke GE. Analytical assessment of trace elements in soils, tomato leaves and fruits in the vicinity of paint industry. Nigeria Res J Rec Sci. 2012;1(4):22-26.

[27] Rozporządzenie Komisji (WE) NR 1881/2006 z dnia 19 grudnia 2006 r. ustalające najwyższe dopuszczalne poziomy niektórych zanieczyszczeń w środkach spożywczych (DzU L 364 z 20.12.2006, s. 5). 


\title{
ZMIANY ZAWARTOŚCI SKŁADNIKÓW POKARMOWYCH W OWOCACH POMIDORA POD WPEYWEM WZRASTAJĄCEJ INTENSYWNOŚCI ŻYWIENIA MANGANEM
}

\author{
Katedra Żywienia Roślin, Uniwersytet Przyrodniczy w Poznaniu
}

\begin{abstract}
Abstrakt: Celem przeprowadzonych w latach 2008-2012 badań była ocena skuteczności stosowania wzrastających stężeń manganu na wartość odżywczą owoców pomidora (Lycopersicon esculentum Mill. cv. 'Alboney $\mathrm{F}_{1}$ ' $\mathrm{i}$ 'Emotion $\mathrm{F}_{1}$ '), wyrażoną zawartością $\mathrm{w}$ nich makro- i mikroskładników. Rośliny uprawiano w wełnie mineralnej, przy zastosowaniu pożywki o następującym składzie (w $\left[\mathrm{mg} \cdot \mathrm{dm}^{-3}\right]$ ): $\mathrm{N}^{-\mathrm{NH}_{4}}-2,2$, $\mathrm{N}-\mathrm{NO}_{3}-230, \mathrm{P}-50, \mathrm{~K}-430, \mathrm{Ca}-145, \mathrm{Mg}-65, \mathrm{Cl}-35, \mathrm{~S}_{-} \mathrm{SO}_{4}-120, \mathrm{Fe}-2,48, \mathrm{Zn}-0,50, \mathrm{Cu}-0,07, \mathrm{pH}-5,50$, EC - 3,00 $\mathrm{mS} \cdot \mathrm{cm}^{-1}$. Badano następujące poziomy żywienia roślin manganem (w $\left[\mathrm{mg} \mathrm{Mn} \mathrm{dm}^{-3}\right]$ ): 0,08 (kontrola); 0,3; 0,6; 1,2 (Eksperyment I); 2,4; 4,8; 9,6; 19,2 (Eksperyment II; opisane jako Mn-0, Mn-0,3, $\mathrm{Mn}-0,6, \mathrm{Mn}-1,2, \mathrm{Mn}-2,4, \mathrm{Mn}-4,8, \mathrm{Mn}-9,6 ; \mathrm{Mn}-19,2)$. Źródłem manganu był siarczan manganawy $\left(\mathrm{MnSO}_{4} \cdot \mathrm{H}_{2} \mathrm{O}\right.$, $32,3 \% \mathrm{Mn})$. Wartość odżywcza owoców pomidora istotnie zmieniała się pod wpływem stosowania szerokiego zakresu stężeń manganu. Wykazano znaczne obniżenie zawartości fosforu (Eksperyment I, II), potasu (Eksperyment II), wapnia (Eksperyment I, II) i magnezu (Eksperyment I, II). Mangan wpływał na obniżenie zawartość pozostałych mikroskładników metalicznych (Fe, $\mathrm{Zn}, \mathrm{Cu})$ w owocach. Odmiana miała istotny wpływ na zawartość: azotu (poza Mn-2,4, Mn-4,8, Mn-9,6), potasu (Eksperyment II poza Mn-4,8), wapnia (poza Mn-0,6, Mn-2,4), magnezu (poza Mn-0,3 i Mn-2,4), żelaza (poza Mn-1,2), manganu i cynku (poza kombinacją kontrolną) oraz miedzi (poza Mn-0,6 i Mn-1,2). Największą zawartość N, Ca i Mg w owocach stwierdzono w przypadku aplikacji $\mathrm{Mn}-0$, podczas gdy $\mathrm{P}$ i $\mathrm{K}$ - przy $0,3 \mathrm{mg} \mathrm{Mn} \cdot \mathrm{dm}^{-3}$, a najmniejsze zawartości składników (poza $\mathrm{N}$ ) w przypadku Mn-19.2 (Eksperyment II). Obniżenie zawartości składników wynosiło (\% zmian składnika: zawartość najmniejsza do zawartości największej): N (11,3); P (48,1); K (24,8); Ca (75,4); Mg (57,5); Fe (59,2); $\mathrm{Zn}(65,4) ; \mathrm{Cu}(43,7)$
\end{abstract}

Słowa kluczowe: mangan, owoce pomidora, makroskładniki, mikroskładniki 